Journal of K6, Education, and Management(J-K6EM)

Vol. 2, No. 2, 2019, pp. 97-I06. ISSN 2580-2I35

\title{
Effect of Education and Income Levels and Parenting Patterns on Children's Social Behavior
}

\author{
Hadisa Putri ${ }^{1}$, Ahmad Suriansyah ${ }^{2}$, Erny Wahdini ${ }^{3}$ \\ ${ }^{1}$ Departement of in Early Childhood Education, Universitas Lambung Mangkurat, Banjarmasin and 70123 \\ Indonesia \\ ${ }^{2}$ Department of in Education Management, Universitas Lambung Mangkurat, Banjarmasin and 70I23, Indonesia \\ ${ }^{3}$ Departement of in Early Childhood Education, Universitas Lambung Mangkurat, Banjarmasin and 70123 \\ Indonesia
}

\begin{tabular}{|c|c|}
\hline ARTICLE INFO & A B STRACT \\
\hline \multirow[t]{2}{*}{$\begin{array}{l}\text { Article history } \\
\text { Received: June } \\
\text { Revised: August } \\
\text { Accepted: September } \\
\text { Keywords: Income Levels, } \\
\text { Levels of Education, Par- } \\
\text { enting Styles and Chil- } \\
\text { dren's Social Behavior }\end{array}$} & $\begin{array}{l}\text { The purpose of this study was to analyze the influence of education level, income } \\
\text { level, and parenting patterns on children's social behavior using the path analysis } \\
\text { method. This research is a descriptive study. The sample of the study was } 257 \\
\text { children 5-6 years in I I TK Sambas District, West Kalimantan, cluster sampling } \\
\text { was chosen using the Slovin formula from a population of } 684 \text { children in the } \\
\text { Kindergarten of Sambas District, West Kalimantan. Data collection uses question- } \\
\text { naires, documentation and observation. The results showed that income levels in- } \\
\text { fluence parenting style, education level influences parents' parenting style, income } \\
\text { level influences children's social behavior, education level influences children's so- } \\
\text { cial behavior, parenting parents influence children's social behavior, parenting par- } \\
\text { ents are an intermediary influence the level of income on children's social behavior } \\
\text { and level of education on children's social behavior. Children's social behavior is } \\
\text { influenced by the level of education and income of parents, both directly and indi- } \\
\text { rectly through parenting. }\end{array}$ \\
\hline & $\begin{array}{l}\text { CC) () } 2019 \text { The Authors. Journal of K6, Education, and Management (j- } \begin{array}{l}\text { (C) } \\
\text { K6EM). ISSN: 2580-2135. Published by Graduated Program of Educational } \\
\text { Management, Universitas Lambung Mangkurat, Banjarmasin 70123, Indone- }\end{array} \\
\text { sia. This is an open access article under the CC-BY-SA license. }\end{array}$ \\
\hline
\end{tabular}

${ }^{*}$ Correspondence: Hadisa Putri; hadisaputri921@gmail.com 


\section{Introduction}

Children are assets and the next generation of a nation so it is important to form a quality child. The quality of a child can be seen from the quality of the child's growth. But until now, the delay in growth and development in children is still a serious problem in developed and developing countries in the world.

According to Noorhapizah \& Dahlina (2016), education is basically a process of maturing quality of life where education focuses on the formation of superior personalities with an emphasis on the process of maturity of logic, heart, moral and temporary faith.

According to Wahyu \& Maimunah (2018), early age children have a critical and strategic age in education which can influence one's education process and produce conducive ways in developing skills, talents, physical, cognitive, linguistic, social, emotional, and spiritual. According to Indrijati (2017), states that the success of an institution is inseparable from the role of the first and main family environment because the family where they learn to recognize personality as social beings and conscience formation, and the first family environment that can harmonize and eventually become smart in shaping and growing a child's personality.

The importance of children's social behavior to be investigated to provide stimulus for children's social behavior in socializing in real life. As for what needs to be developed from the children's social behavior including the way children associate still likes to choose their friends, children do not want to help their friends due to the lack of concern for their children to their friends and the social behavior of children in communication still likes to speak loudly.

According to Hurlock in (Susanto, 2017), then social behavior what is important to be developed for early childhood is the pattern of behavior including children able to respect friends, both respecting property, opinions, the work of friends, or conditions that exist in friends. Respect the condition of others, for example children do not mock or isolate other children whose limbs are imperfect, disabled, physically lacking, and psychologically. The development of social behavior can also be directed to teach children to help others (helping other), unselfishness, an attitude of togetherness, an attitude of simplicity and independence, which at this time these attitudes have begun to disappear from the attention of educators, both at the education level of the Park Childhood, as well as at a higher level of education.
Family social status has a significant influence on the behavior of children with parents, especially in fathers in earning a living. If the family social status of the child is the same as the peer status seen from the level of income of the parents, then the child will feel proud of their parents. If the child knows family status is lower, then the child feels embarrassed and feels inferior, so the child is very critical of his parents, especially the two parents (Hurlock, E. B. 1978).

According Hosokawa, Rikuya, \& Katsura (2017), family income and education level of each parent are related to social skills by internalizing and externalizing those who have problems, both directly and indirectly, while ecologically. According to Hurlock (1978), shows that poor parents will have an impact on parents' psychological difficulties, namely the practice of raising children in emotional problems, children's behavior, parents who are in slum homes (or without homes), job loss, difficulty finding food, and not controlling the lives of parents tend to be restless, controlling the lives of parents tend to be restless, depressed, and easily offended, rude and excessive so that it will affect children who have difficulty playing with peers, lack confidence, and engage in anti-social activities.

With the level of parental education, the child will get directly good parenting aimed at good social development. The role of parents is very important in the activity of providing parenting to their children, basically parents are forming the character and basis of behavior which will later affect the phase of social development of children. Thus parents with the level of education, children get insight into knowledge to provide parenting to children with the aim of parents toward the direction of its development. While the level of parental education indirectly with parenting patterns of social behavior of children, also depends on the time and energy to provide physical touch and energy possessed by parents at home.

According to (Erikson, 1993), an expert in the field of child development explains the importance of the role of parents in developing the psychosocial aspects of children's parents that provide warmth, comfort, love and affection for children from an early age, will enable children to develop a sense of trust in their environment if you get through these stages properly, children will more easily develop atonomy and initiative in themselves.

Baumrind (I966), mentions that there are three models of parenting, namely permissive, authoritarian and authoritative related to the relationship of child behavior with the discipline component. The relation- 
ship between freedom and control is examined and the position of defense that authoritative control can effectively produce children's behavior that is well socialized and intentional individually

Basically children are individual beings who build their own knowledge. Theoretically based on aspects of its development, a child can learn as well as possible if his physical needs are met and they feel safe and psychologically comfortable (Sujiono, 2013). In addition, the child needs to pay attention to building their own knowledge, children learn through social interaction with adults and other children learn through play, children's interests and curiosity motivate them to learn while playing and individual variations in development and learning (Sujiono \& Sujiono B, 2010).

Based on the above problems, this study aims to describe and analyze based on the above problems, this study aims to describe and analyze the relationship between education level, income level, and parenting patterns on children's social behavior.

\section{Methodology}

This type of researchuses quantitative with descriptive analysis and path analysis. Ridwan (2012), path analysis is used to analyze patterns of relationships between variables with the aim of knowing the direct or indirect effects of a set of independent.

The study sample consisted of 257 children aged 5-6 years spread out II TK selected by cluster sampling using the Slovin formula from a population of 684 children in the Kindergarten of Sambas Subdistrict, Sambas District, West Kalimantan. Data collection using a questionnaire consists of income level, education and parenting style variables, while observations on variables of children's social behavior. Collection of documentation data to complement research such as school profiles consists of the state of the teacher and child. In accordance with the conceptual relationship model between variables as shown in the following figure:

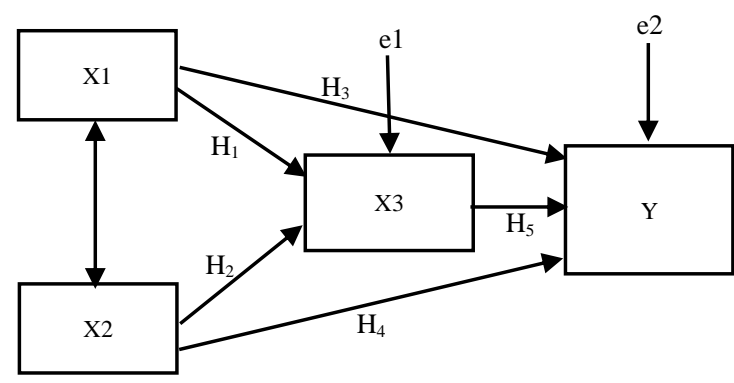

Figure I

Influence Diagrams between Variables $\mathrm{X}_{1}, \mathrm{X}_{2}, \mathrm{X}_{3}$ and $\mathrm{Y}$

Information:

$\mathrm{XI}=$ Parental income level

$\mathrm{X} 2=$ Parental education level

$\mathrm{Z}=$ Parenting pattern

$\mathrm{Y}=$ Child social behavior

\section{Findings and Discussion}

The results of the descriptive statistical analysis of respondents to the research variables, namely the level of income, level of education, parenting parents, and social behavior of children

Table I Frequency Distribution Respondents in the Level of Income of Parents

\begin{tabular}{lccc}
\hline & Category & Frequency & Presentation \\
\hline Low & & 13 & $5.1 \%$ \\
Medium & 89 & $34.6 \%$ \\
More than Medium & $\mathrm{I} 20$ & $46.7 \%$ \\
High & & 30 & $11.7 \%$ \\
Very high & & 5 & $1.9 \%$ \\
& Total & 257 & 100 \\
\hline
\end{tabular}

Table 2 Frequency Distribution of Parents' Education Level

\begin{tabular}{|c|c|c|}
\hline Category & Frequency & Presentation \\
\hline Primary school & 3 & $1.2 \%$ \\
\hline Junior high school & 64 & $24.9 \%$ \\
\hline Senior High School & I I5 & $44.7 \%$ \\
\hline Bachelor & 65 & $25.3 \%$ \\
\hline Master & I0 & $3.9 \%$ \\
\hline Total & 257 & 100 \\
\hline
\end{tabular}


ISSN 2580-2135

Table 3 Frequency Distribution of Parenting Parents

\begin{tabular}{lcc}
\hline \multicolumn{1}{c}{ Category } & Frequency & Presentation \\
\hline Authoritarian & 40 & $15.6 \%$ \\
Democratic & 155 & $60.3 \%$ \\
Permissive & 62 & $24.1 \%$ \\
\multicolumn{1}{c}{ Total } & 257 & 100 \\
\hline
\end{tabular}

Table 4 Distribution of Child Social Behavior

\begin{tabular}{lccc}
\hline \multicolumn{1}{c}{ Category } & Frequency & Percentage \\
\hline Low & & 27 & $10.5 \%$ \\
Is being & 74 & $28.8 \%$ \\
High & & 128 & $49.8 \%$ \\
Very high & & 28 & $10.9 \%$ \\
& Total & 257 & I00 \\
\hline
\end{tabular}

For the next stage is the interpretation of the results of path analysis with multiple regression tests for each structure I model and structure model II. The equation with the summary results in table 5 below:

Table 5 Summary of Path Analysis Results

\begin{tabular}{lcccc}
\hline \multicolumn{5}{c}{ Structure Model I } \\
\multicolumn{1}{c}{ Income Level, Education Level on toward Parenting Parents } \\
\hline Variable & Path coefficient & $\mathrm{T}$ & $\mathrm{P}$ & $\mathrm{R}^{2}$ \\
\hline Income Levels & $0.18 \mathrm{I}$ & 2.914 & 0.004 & $.07 \mathrm{I}$ \\
Levels of Education & 0.156 & 2.504 & 0.013 & \\
\hline
\end{tabular}

Structure Model II

Income Levels, Levels of Education, and Parenting Styles and Children's toward Social Behavior

\begin{tabular}{lcccc}
\hline \multicolumn{1}{c}{ Variable } & Path coefficient & $\mathrm{T}$ & $\mathrm{P}$ & $\mathrm{R}^{2}$ \\
\hline Income Levels & 0.156 & 2.777 & 0.006 & \\
Levels of Education & 0.423 & 7.593 & 0.000 & 0.275 \\
Parenting Styles & 0.115 & 2.077 & 0.039 & \\
\hline
\end{tabular}

Table 6 Summary of Decision on Hypothesis Testing $\mathrm{H}_{1}, \mathrm{H}_{2}, \mathrm{H}_{3}, \mathrm{H}_{4}$, and $\mathrm{H}_{5}$

\begin{tabular}{|c|c|c|c|}
\hline \multicolumn{3}{|c|}{ Hypothesis } & \multirow{2}{*}{$\begin{array}{l}\text { Decision } \\
\text { Received }\end{array}$} \\
\hline $\mathrm{H}_{\mathrm{I}}$ & $\begin{array}{l}\text { There is a positive influence and significance between the Income Levels and Parent- } \\
\text { ing Styles }\end{array}$ & 0.004 & \\
\hline $\mathrm{H}_{2}$ & $\begin{array}{l}\text { There is a positive influence and significance between the level of education and } \\
\text { Parenting Styles }\end{array}$ & 0.013 & Received \\
\hline $\mathrm{H}_{3}$ & $\begin{array}{l}\text { There is a positive influence and significance between the level of income and social } \\
\text { behavior of children }\end{array}$ & 0.006 & Received \\
\hline $\mathrm{H}_{4}$ & $\begin{array}{l}\text { There is a positive influence and significance between the level of education and the } \\
\text { social behavior of children }\end{array}$ & 0.000 & Received \\
\hline $\mathrm{H}_{5}$ & $\begin{array}{l}\text { There is a positive influence and significance between Parenting Styles and children's } \\
\text { social behavior }\end{array}$ & 0.039 & Received \\
\hline
\end{tabular}

Table 7. Summary of Hypothesis Testing Decision $\mathrm{H}_{6}$, dan $\mathrm{H}_{7}$

\begin{tabular}{|c|c|c|c|c|}
\hline & \multirow{2}{*}{ Hypothesis } & \multicolumn{2}{|c|}{ Relationship Coefficient } & \multirow{2}{*}{ Decision } \\
\hline & & Direct & Indirect & \\
\hline $\mathrm{H}_{6}$ & $\begin{array}{l}\text { Parenting Styles is an intermediary influencing the level } \\
\text { of income and social behavior of children }\end{array}$ & 0.156 & 0.021 & Not accepted \\
\hline $\mathrm{H}_{7}$ & $\begin{array}{l}\text { Parenting Styles is an intermediary for influencing the level } \\
\text { of education and social behavior of children }\end{array}$ & 0.423 & 0.018 & Not accepted \\
\hline
\end{tabular}


Frequency descriptive analysis in table I-4 to answer the first hypothesis about the description of income level, level of education, parenting and social behavior of children with research hypotheses that have been formulated with decisions are given in Table 6 and Table 7. For Table 6 is a decision summary HI, $\mathrm{H} 2$, H3, H4, and $\mathrm{H} 5$ with criteria of significance values less than 0.05, accepted. Table 7 is a summary of the decisions of testing hypotheses $\mathrm{H} 6$ and $\mathrm{H} 7$ provided that the coefficient of direct influence is greater than the coefficient of indirect influence, the hypothesis is not accepted, at most in the more than moderate category there are 120 people. With a percentage of $46.7 \%$. Whereas for the education level of parents with the most graduates in the study there were II5 high school/vocational/MA graduates with a percentage level of $44.7 \%$, for the most parents parenting was democratic parenting with I55 people with a percentage of $60.3 \%$ and behavior The highest social categorization for categorization is 128 children with a percentage of $49.8 \%$.

\section{There are Effects of Income Levels and Parenting Patterns}

Based on table 5, structural model I found that there is a direct influence on the level of income and parenting with the calculation result 0.004 smaller than 0.05. Thus there is an influence between the level of income with parenting parents because the number 0.004 is smaller than the number 0.05. While the magnitude of the level of income correlation and parenting path coefficient is 0.I8I. This finding makes perfect sense that more than moderate parental income will make it easier to develop in meeting their needs and has implications for parenting.

This finding makes perfect sense that more than moderate parental income will make it easier to develop in meeting their needs and has implications for parental care. His findings are very plausible that more than moderate parent income will make it easier to develop in meeting their needs and have implications for providing better caregivers in early childhood development including patterns of interaction of psychological development and personality of children, emphasizing the development of feelings child curiosity, control in children, the ability to delay desires for a long period of time, and sensitivity in relationships with others are more open to new things.

The findings of this study are supported by Dong \& Dajun (2015), statement stating that the higher the socio economic level, the smaller the pressure of par- enting style, in enabling them to provide more education, support, and care for children. This was confirmed by (Djola, 2002) which states that the level of family income contributes to meeting the basic needs of the family, the attention and affection the child receives. The results of the study according to Djamarah (20I4), the quality and intensity of parenting are influenced by factors of parental education, employment, socio-economic conditions, ethnic customs and so on.

\section{There is an Influence of Education Levels and Parent- ing Pattern}

For table 5 with structural model I, it was found that there was a direct influence on the level of education with parenting patterns with a correlation value of 0.013 less than 0.05 .

This finding shows that high levels of education will contribute to providing good care. According to Roubinov \& Boyce (2017), that income and higher education with national status can also provide higher social capital indirectly influencing childcare strategies through opportunities for education and employment in guiding children. This is in agreement with Muryono (2009), stating that the higher the level of education of parents, the better the way to eliminate children.

This opinion according to Soetjiningsih (I998), states that the level of education of parents is one of the most important factors in fostering child development. Because with education good parents can receive all information from outside, especially about how to care for a good child. In addition, the findings of this study are consistent in (Shaver, 1972) study stating that education is provided by parents in the family environment through socialization so as to form habits, desires, and habits that exist in society. According to Sunain (2017), the educational background of parents has a positive contribution to how to care for children, while parenting has a relationship with the level of child development. This means that the higher the level of education of parents, the better the way to care for children and as a result the development of affected children runs positively. Conversely the lower the level of education of parents will be less good at raising children, so that the growth of children runs less profitable.

In line with the opinion of Darmiyati \& Amalia Sri Rezeki (2017), mentioning parents' concern for the education process of their sons and daughters in school is formed from the accumulation of experiences, events 
and internal and external events. Internal factors include the background of parents' lives, relationships or interactions between parents and their sons and daughters, parents' education level, economic level or parents' income. While external factors include local values and culture, awards from education managers, educational outcomes from sons and daughters, shared commitment between parents and school.

\section{There is an Influence of Income Levels and Children's Social Behavior}

Based on the research findings, it can be seen from table 5 of structural model II that there is an influence of the level of parental income on social behavior with a significance of $0.006<0.05$. This means that there is an influence between the level of parental income on social behavior with a result value of 0.006 smaller than 0.05. Thus from the results of this study the level of parental income is a strong predictor of many aspects of a child's personality. Children from families with higher income levels are more patient, tend to behave more prosocially and tend not to cause problems.

This study is consistent with findings Hoff, Laursen, \& Tardif (2002), suggesting that higher socioeconomic strata change more in responding to changes in child development in contrast to parents in lower socio-economic strata. In the opinion of Devries, Rathmann, \& Gebhardt (2018), states that children with higher economies tend to show fewer social problems and more prosocial behavior.

In addition the findings of this study are in agreement with Desmita (2010), stating that the background of economic factors influences child development. In line with Santrock (2002), that family economic conditions and care affect children's development. Meanwhile Deckers, Falk, Kosse, \& Horisch (2015), explained that the socio-economic status of parents is a strong determinant of many aspects of a child's personality. Children from families with higher socioeconomic status tend to be more prosocial. According to (Necsoi, Porumbu, \& Beldianu, 2013), states that children from low income, less educated, single parents and large families have poor performance in schools than those with higher incomes, more educated, two parents and families small.

This study was strengthened from the results of Kelly, Sacker, Bono, M, \& Marmot (20II), mentioning that the markers of learning at home, family routines and psychosocial environment are socially motivated, the highest income families are more likely to have a favorable profile than low income families. Thus the level of parents' income towards children's social behavior is very influential, this is consistent with (Ogburn, 1992), material elements are the main source in terms of progress, especially with the presence of more sophisticated technology.

\section{There is an Influence of Education Level and Child Social Behavior}

Based on the research findings, table 5 of the structural model II influences the level of parental education and social behavior of children by having a significance value of 0,000 less than 0.05 and having a correlation coefficient of 0.423 .

Thus based on the results of this study that the level of parental education contributes to social behavior is due to parents with higher education having the ability and knowledge in developing cognitive, psychomotor and affective aspects.

Based on the results of research from Hayati (2017), there are differences in children's social development based on the level of education of parents. Children from highly educated parents have better social development, the more knowledge and insight parents have, the easier and more appropriate to use in everyday life. Highly educated parents need better care for children, not only in their social development but also in developing other aspects of the child.

According to Utami, (2008), the education level of parents has an influence on the growth and development of children, the higher the level of education of parents the better the development of children. Education between parents and children is very important. Parental education can affect children depending on communication with each other, depending on the relationship between parents and children. Based on the results of this study according to Lestiawati (2013), the level of education in the family in terms of social aspects, the family is a unit of life (social system), and the family provides a learning situation. As a social system, the family consists of father, mother and child. Family ties help children develop friendship, love, interpersonal relationships, cooperation, discipline, good behavior. Caring for and educating children is part of the role of parents to create a conducive social environment.

\section{There is an Influence Between Parental Parenting and Children's Social Behavior}


Based on the research findings, it shows that table 5 of the structural model II influences the parental complaining pattern of children's social behavior which has a significance value of 0.039 smaller than 0.05 with a correlation coefficient of O.II5. Based on the results of the research above that the child's social behavior as a form of behavior that cannot be separated from the role of parenting in the family in developing behavioral attitudes towards child development, especially the development of children's social behavior and parenting patterns are very important influence on the child's ability to resolve the problem.

The findings of this study have compatibility Marsiyanti \& Harahap (2000), states that parenting is a characteristic of style, education, coaching, supervision, attitudes, relationships and so on that are applied by parents to their children. The pattern of parenting will affect the development of children from childhood to adulthood. This finding is in accordance with Egon, Marius, \& Herbert (2018), stating that the protective effects of bond-based relationship skills from parents (parent bonding, involvement, monitoring, enrichment) are intermediaries for early childhood psychosocial development.

According to Darmiyati \& Amalia Sri Rezeki (2017), that children want to be involved in new, challenging, and fun activities. Children are explorative, adventurous because children are motivated by great curiosity about something. Children want to try and learn new things. Basically, children can build and create their own knowledge, so it is important to be directly involved in the learning process.

Whereas according to Konnie \& Alfred (2013), states that parenting style has an influence on children's social development. Parenting is a very important factor in shaping character, personality, emotional intelligence, the formation of self-concept and the value of planting so that children can adjust to their surroundings so that children can be independent, grow and develop in a healthy and optimal way.

Other findings reinforce the results of research including (Hurlock, 1978) Hurlock states that: children who grow up in a culture that tolerates some have individuality will be accepted by the group even though their behavior is not the same as the behavior of other children of the same age. Conversely in the rules of culture of parents who are always strict, people who do not adjust to any degree will be punished by social rejection. The more assertive the concept of the cultural group about the "ideal person" is the person who will best fit the pattern of life that has been determined for group members, the greater the expected adjustment as a condition of social acceptance.

According to Suriansyah \& Aslamiah (2015), mentioning collaborative activities in the community plays an important role as social influences that greatly affect student achievement in school. Meanwhile children who received strong support from their families showed better performance than children who lacked family support.

\section{There is an Indirect Effect Between Income Levels and Children's Social Behavior through Parenting Parents}

Based on table 7 of the calculation results it is known that the value of the direct effect is 0.156 and the indirect effect of $0.02 \mathrm{I}$ means that the value of the direct effect is greater than the value of the indirect effect can be concluded not accepted. Thus the influence of income levels on social behavior is greater without going through parenting means that with a higher level of parent income, all the fulfillment of the needs to be obtained can be fulfilled both from all material and other means for child development.

According to Kaiser, Li, Pollmann-Schult, \& Song (2017), states that the level of behavior problems of higher or poorer children is not solely related to childcare practices. Qualitative evidence for Germany shows that poor parents are able to be adequate parents, despite severe financial difficulties. Whereas according to Nucci \& Narvaez (2016), there are three moral elements of educational goals namely; (a) the spirit of discipline, (b) the association of social groups and the spirit of Altruism means that the formation of morality requires us to be bound or connected with groups. Thus when children are familiarized with the cultural heritage of society, children can realize the meaning of social identity and altruism, (c) autonomy or selfdetermination.

\section{There is an Indirect Effect Between Parental Education Levels and Children's Social Behavior through Parent- ing Parents}

Based on table 7 from the calculation results it is known that the value of the direct effect is 0.423 and the indirect effect is 0.018 which means the value of the direct effect is greater than the value of the indirect effect concluded that it is not accepted. Thus the presence of a higher level of parental education will have an influence on the mindset and orientation of education provided to their children. The higher the education that is owned by parents, the more it will expand and complete the mindset in educating their children. Con- 
ditions in the form of educational background of parents is one thing that is definitely found in childcare.

The findings of this study are consistent with previous studies as this study examines (Davis-Kean, 2005), the process of socio-economic status, especially education and parents' income, indirectly related to children's academic performance through parental trust and parenting. Using structural equation modeling techniques, found that socioeconomic factors are related indirectly to children's academic performance through parental behavior. In addition, for AfricanAmericans and European-Americans, the indirect relationship of parental education with parental behavior is substantially related to the expectations of parental education for children's behavior.

The results of these studies are reinforced according to Hurlock (1978) states that children who come from well-educated families increase vocabulary more than children who come from a family of educated parents is not high. This is also found Soetjiningsih (I998) that the level of education of parents is also one of the family factors and customs that are important in the development of children, because with good education, parents can receive all information from outside, especially on how to care for children who well, how to maintain the health of their children, their behavior and so on.

\section{Conclusions and Recommendations}

Based on the results of data analysis and discussion as described above, it can be concluded that there is there is an influence of the level of income and parenting, the influence of the level of education and parenting, there is a level of income and social behavior of the child, there is an influence of the level of education and social behavior, there is an influence of the level of income and parenting, and there is an influence of the level of income with the social behavior of the child through the pattern parenting and there is a significant influence between the level of education and social behavior of children through parenting.

Children's social behavior is influenced by the level of education and income of parents both directly and indirectly through parenting parents for children. In addition, the level of parental education is also very influential on the way, patterns, thinking frameworks and perceptions and personality development of children. The level of parental education directly or indirectly will affect the pattern of communication between parents and children in the family environment. Higher levels of parental education will provide more environmental stimulation (physical, social, emotional, and psychological) for their children compared to parents whose education level is low. In addition to the level of income parents are considered to have a role in the family, especially for parenting applied.

In addition, based on the results of research and conclusions that can be drawn from this study, it is suggested to education stakeholders to strengthen cooperation between parents and the Education Office in making parenting programs and always communicating in order to foster better child development.

\section{Acknowledgment}

We would like to thank you for supporting this research in writing this journal article, the authors were greatly assisted by many parties, especially principals, teachers and parents from the Sambas Kindergarten, Sambas District, West Kalimantan, and the Sambas District Education and Culture Office provide opportunities and recommend conducting research as well as assistance in obtaining data so that this journal article can be completed properly.

\section{References}

Baumrind, D. (I966). Effects of Authoritative Parental Control on Child Behavior. Child Development, 37 (4), 887-907.

Darmiyati, \& Amalia Sri Rezeki. (2017). Variations of Demonstration Learning Model in Expressing Images in Detail Using Direct Practice Method in Early Childhood. Journal of K6, Education, and Management, I (I), I3-20.

Davis-Kean, P. E. (2005). The influence of parent education and family income on child achievement: The indirect role of parental expectations and the home environment. Journal of Family Psychology, I9(2), 294304. https://doi.org/IO.I037/08933200.19.2.294

Deckers, T., Falk, A., Kosse, F., \& Horisch, H. S. (2015). How Does Socio-Economic Status Shape a Child's How Does Socio-Economic Status Shape a Child' s Personality? In IZA Discussion (pp. I-35). Germany: Forschungsinstitut zur Zukunft der Arbeit Institute for the Study of Labor.

Desmita. (2010). Psikologi Perkembangan Peserta Didik. Bandung: PT. Remaja Rosdakarya.

Devries, J. M., Rathmann, K., \& Gebhardt, M. (2018). How Does Social Behavior Relate to Both Grades and Achievement Scores? Social Behavior and Achievement, 9(June), I-8. https://doi.org/I0.3389/fpsyg.2018.00857

Djamarah, S. . (2014). Pola Asuh Orang Tua dan 
Komunikasi dalam Keluarga: Upaya Membangun Citra Membentuk Pribadi Anak. Jakarta: Rineka Cipta.

Djola, R. (2002). Hubungan Antara Tingkat Pendapatan Keluarga dan Pola Asuh Dengan Status Gizi Anak Balita di Desa Bongkudai Kecamatan Modayag Barat. Fakultas Kesehatan Masyarakat Universitas Sam Ratulangi.

Dong, Z., \& Dajun, Z. (20I5). The Relationship between Family's Social Economic Status and Psychological Suzhi of Middle School Students: The Intermediary Effect of Parenting Style. Open Journal of Social Sciences, O3(I2), 93-99.

https://doi.org/I0.4236/jss.20I5.3120I0

Egon, B., Marius, N., \& Herbert, B. (2018). The Relationship between Peer Victimization, Perceived Parental Support, Family Characteristics and Internalizing Symptoms . A Cross-Sectional Study. The Open Family Studies Journal, IO, 9-20. https://doi.org/I0.2174/I8749224018I00I 0009

Erikson, E. (1993). Chilhood and Society. New York: W.W Norton \& Compony.

Hayati, F. dan I. Y. (2017). Analisis Tingkat Pendidikan Orang Tua Terhadap Keterampilan Sosial Anak di TK Miftahul Ulum Lampakuk. Analisis Tingkat Pendidikan, 4 (I), 5I-60.

Hoff, E., Laursen, B., \& Tardif, T. (2002). Socioeconomic Status and Parenting. (M. Bornstein, Ed.). Florida: Erlbaum.

Hosokawa, Rikuya, \& Katsura, T. (2017). A Longitudinal Study Of Socioeconomic Status, Family Processes, And Child Adjustment From Preschool Until Early Elementary School: The Role Of Social Competence. Child and Adolescent Psychiatry and Mental Health, II (62), I-28.

Hurlock, E. B. (1978). Perkembangan Anak Jilid I, Alih Bahasa Mitasari Tjandrasa dan Muslichah Zarkasih. Jakarta: Kecana.

Indrijati, H. (2017). Psikologi Perkembangan dan Pendidikan Anak Usia Dini. Jakarta: Kencana.

Kaiser, T., Li, J., Pollmann-Schult, M., \& Song, A. Y. (2017). Poverty and child behavioral problems: The mediating role of parenting and parental well-being. International Journal of Environmental Research and Public Health, I4(9).

https://doi.org/I0.3390/ijerphI409098I

Kelly, Y., Sacker, A., Bono, E. D., M, F., \& Marmot, M. (20II). What role for the home learning environment and parenting in reducing the socioeconomic gradient in child development? Findings from the Millennium Cohort Study. Archives of Disease in Childhood, 96(9), 832837.

https://doi.org/IO.II36/adc.2010.1959I7
Konnie, M. M., \& Alfred, K. (2013). Influence of Parenting Styles on the Social Development of Children. Academic Journal of Interdisciplinary Studies MCSER Publishing, Rome-Italy, 2 (3)(3), I23-130. https://doi.org/I0.590I/ajis.20I3.v2n3pI23

Lestiawati, I. M. (2013). Pengaruh Pola Asuh Orang Tua Terhadap Kemampuan Sosial Anak Usia 6-7 Tahun. Jurnal Ilmiah Visi P2tk Paudni, 8 (2), III-II9.

Marsiyanti, T., \& Harahap, F. (2000). Psikologi Keluarga. Yogyakarta: FIP UNY.

Muryono, S. (2009). Empati, Penalaran Moral dan Pola Asuh; Telaah Bimbingan Konseling. Yogyakarta: Gala Ilmu Semesta.

Necsoi, D. V., Porumbu, D., \& Beldianu, I. F. (2013). The Relationship Between Parental Style and Educational Outcomes of Children in Primary School in Romania. Procedia - Social and Behavioral Sciences, 82, 203-208. https://doi.org/I0.1016/j.sbspro.2013.06.24 6

Noorhapizah, \& Dahlina. (2016). Meningkatkan Hasil Belajar Ips Pada Materi Perkembangan Teknologi Menggunakan Model Pembelajaran Cooperative Scriptkombinasi Dengancourse Review Horaydi Kelas Iv SDN Tatah Jaruju Kecamatan Tatah Makmur Kabupaten Banjar. Paradigma, II (2), I-4.

Ogburn, W. F. (1992). Social Change With Respect To Culture And Original Nature. New York: Huebsch, Inc.

Ridwan. (2012). Belajar Mudah Penelitian. Bandung: Alfabeta.

Roubinov, D. S., \& Boyce, W. T. (2017). ScienceDirect Parenting and SES: relative values or enduring principles? Current Opinion in Psychology, I5, 162-167. https://doi.org/I0.1016/j.copsyc.2017.03.00 I

Santrock, J. W. (2002). Life-Span Development: Perkembangan Masa Hidup. Edisi 5 Jilid 2. Jakarta: Erlangga.

Shaver, J. P. (1972). Values and Schooling Perspectives For School People and Parents. Logan: Faculty Association Utah State University Logan.

Soetjiningsih. (1998). Tumbuh Kembang Anak. Surabaya: Airlangga.

Sujiono, Y. N. (2013). Konsep Dasar Pendidikan Anak Usia Dini. Jakarta: PT INDEKS.

Sujiono, Y. N., \& Sujiono, B. (2010). Bermain Kreatif Berbasis Kecerdasan Jamak. Jakarta: Indeks.

Sunain. (2017). Pengaruh Tingkat Pendidikan Orang Tua Terhadap Tingkat Kecerdasan dan Keaktifan Siswa dari Kelas Satu Sampai dengan Kelas Enam Pada Semester I. Pedagogia : Jurnal Pendidikan, 6 (2), I60-I72.

Suriansyah, A., \& Aslamiah. (2015). The Leadership 
Strategies Of School Principals, Teachers, Parents. Cakrawala Pendidikan, XXXIV (2), 234-247.

Susanto, A. (2017). Pendidikan Anak Usia Dini Konsep dan Teori. Jakarta: Bumi Aksara.

Utami, R. B. (2008). Pengaruh Tingkat Pendidikan Dan Tipe Pola Asuh Orang Tua Terhadap Perkembangan Psikososial Anak Prasekolah di Taman Kanak-Kanan Aisyiyah II Nganjuk. Universitas Sebelas Maret Surakarta.

Wahyu, \& Maimunah. (2018). Development of Religious and Moral Values on 4-5 Years Old Children in Imitating Prayer Movement ( Shalat ) Using Simulation and Rewarding Methods. Journal of K6, Education, and Management, I (2), 7-I0. 